\title{
Potential of peel extracts of Punica granatum and Citrus aurantifolia on alloxan- induced diabetic rats
}

Sivasangari Ramya ${ }^{1}$, Vijayanand Narayanan ${ }^{2 *}$, Boomibalagan Ponnerulan ${ }^{3}$, Eswaran Saminathan $^{4}$ and Uthirapandi Veeranan ${ }^{5}$

\begin{abstract}
Background: Peel is one of the major by-products in fruit processing industry. Fruit products (non-edible parts) are also considered as waste products and often discarded in the environment. Fruit peels are now serving as one of the primary sources for isolation and extraction of secondary metabolites in pharmaceutical industry. The present investigation was carried out to screen the phytochemical constituents and HPTLC analysis of peel extracts of Punica granatum and Citrus aurantifolia and their antidiabetic potential in alloxan-induced diabetic rats.

Results: Among the different solvent extracts, methanol solvent extract was found to possess more amounts of secondary metabolites. In addition, HPTLC analysis of the plant samples revealed the presence of 13 peaks in both the plants by using gallic acid as marker. Different biochemical parameters such as blood glucose, cholesterol, protein, urea, creatinine, and triglycerides level were subjected for estimation by collecting the blood samples from the treated diabetic rats after 21 days. A sharp decline in blood glucose, cholesterol, triglycerides, creatinine, and urea level was noticed when methanolic extracts of Punica granatum and Citrus aurantifolia were given to experimental animals when compared with negative control. However, protein and weight of the animal were found to be enhanced when treated with methanolic extracts of both the plants.

Conclusion: It can be concluded that fruit peels of both the plants exhibited antidiabetic potential on alloxaninduced diabetic rats which can be attributed to wide range of active pool of secondary metabolites. Further, screening and isolation of secondary metabolites along with their mode of action is required for effective use of plant-based drugs as antihyperglycemic agent.
\end{abstract}

Keywords: Fruit Peel, Punica granatum, Citrus aurantifolia, Antidiabetic activity, Gallic acid, HPTLC analysis

\section{Background}

Diabetes mellitus (DM) is a major chronic metabolic disorder and an extremely serious condition from both clinical and public health standpoints. It is recorded that every 5 th Indian have diabetes by 2025 , it may be assumed 40 million diabetics in India expected to be 70 million by 2025 [1]. Diabetes mellitus can directly affect serum lipid levels causing diabetic dyslipidemia which is

\footnotetext{
* Correspondence: vijayapsac@gmail.com

${ }^{2}$ Department of Botany, Arumugam Pillai Seethai Ammal College,

Thiruppathur, affiliated to Alagappa University, Karaikudi, Tamil Nadu, India

Full list of author information is available at the end of the article
}

one of its complications [2]. Among the available therapeutic agents, insulin, metformin, sulfonylureas (SU), and thiazolidinediones (TZDs) are mostly used for the control of diabetes [3]. Plants are an excellent source of drugs, and many of the currently available drugs have been derived directly or indirectly from them [4]. It is obvious due to the richness and complexity of the compounds in plants. A multiple targeting is a double-edged sword in diabetes therapies. The multiple targets associated with antidiabetic herbal medicine could play a beneficial role in the control of diabetics. 
Fruit and vegetable wastes are used to extract and isolate potential bioactive compounds and used in the food, pharmaceutical, cosmetics, and textile industries. Studies have revealed that appreciable quantity of phytochemical compounds and other essential nutrients are present in the seeds, peels, and other components of fruits and vegetables [5]. Likewise, several works have confirmed that fruit peel parts possess phenolic compounds and exhibit higher antioxidant activity [6]. Even though several attempts are carried out on antidiabetic activities of medicinal plants and animal-based studies, studies regarding fruit peels are scanty. Therefore, the present study was made to evaluate the antidiabetic potential of fruit peel of Punica granatum and Citrus aurantifolia on alloxaninduced diabetic rats and identify the bioactive compounds using HPTLC analysis.

\section{Methods}

\subsection{Collection of plant materials}

The fruits of Citrus aurantifolia and Punica granatum which were procured from Tamil Nadu Agricultural College and Research Institute (TNAU), Madurai, Tamil Nadu was identified and authenticated by an botanist (also an expert in plant taxonomist) from our institute by referring standard taxonomic characteristic features (keys) according to Flora of Madras Presidency [7] and the Flora of Tamil Nadu Carnatic [8]. The voucher samples (SN-9718) and photographs were deposited in the institute for future reference.

\subsection{Selection and maintenance of experimental animals}

Albino Wister strain rats of both sex, 6 months old that weighed $180-220 \mathrm{~g}$ with a mean weight of $200 \mathrm{~g}$ were used in this study. The animals were allowed to acclimatize for 2 weeks in the animal house at the Department of Pharmacy in Ultra College of Pharmacy, Madurai. The rats were housed in polypropylene cages, maintained under standard laboratory conditions. Animals were fed with standard laboratory pellets diet and water. Animal studies were done at Department of Pharmacy in Ultra College of Pharmacy, Madurai and experimental protocols and procedures were approved by Institute of Animal Ethics Committee of Ultra College of Pharmacy Institute (approval number: MKU/IAEC/ KMCP/88/P9718 Ph.D./2013).

\subsection{Extraction of Punica granatum and Citrus aurantifolia} The fruit peel of Punica granatum and Citrus aurantifolia were washed thoroughly with running tap water to remove dust particles, adhering epiphytes, etc. They were air-dried and crushed into powder in a grinding machine. The powder $(0.5 \mathrm{~kg})$ was extracted in an Erlenmeyer flasks with different solvents, viz., 90\% petroleum ether, ethyl acetate chloroform and methanol, and aqueous at room temperature. The whole extract was combined, filtered (Whatman filter paper no.1), and concentrated at $40{ }^{\circ} \mathrm{C}$ in vacuum and finally, the extract was freeze-dried to get $50 \mathrm{~g}$ of crude extract.

\subsection{Preparation of aqueous extract}

Fresh plant materials $(0.5 \mathrm{~kg})$ were harvested and were surface sterilized with $0.1 \%(\mathrm{w} / \mathrm{v}) \mathrm{HgCl}_{2}$ solution for 5 min. The plant material was grounded with mortar and pestle and the tissue was centrifuged at $3500 \mathrm{rpm}$ for 20 min. The supernatant alone was taken as aqueous extract. All the extracts were concentrated by distillation and evaporated to dryness using a flash evaporator. After evaporation, each of the solvent extracts was weighed and preserved at $5{ }^{\circ} \mathrm{C}$ in airtight bottles.

\subsection{Phytochemical analyses of the fruit peel of Citrus aurantifolia and Punica granatum}

Phytochemical screening of crude solvent extracts were performed using the following reagents and chemicals: alkaloids with Wagner reagent, tannins with $5 \%$ ferric chloride, saponins with ability to produce foam by adding water and olive oil, carbohydrates with Molish reagents and concentrated sulfuric acid, glycosides with glacial acetic acid, ferric chloride and concentrated sulfuric acid, steroids with chloroform, acetic anhydride and concentrated sulfuric acid, terpenoids with chloroform and concentrated sulfuric acid, and fixed oil using spot and oil staining methods $[9,10]$.

\subsection{HPTLC analysis}

\subsubsection{Development of chromatogram}

Sample solutions were applied onto the plates with an automated Camag HPTLC system comprising of Linomat $\mathrm{V}$ as sample applicator (Camag, Muttenz, Switzerland) and TLC Scanner III controlled by win CATS software 1.4.3 was used for quantitative evaluation [11]. A TLC scanner III with win CATS software was used for scanning the TLC plates, and pre-coated silica gel aluminum plates $60 \mathrm{~F}_{254} 20 \times 10 \mathrm{~cm}$ with $0.2 \mathrm{~mm}-\mu \mathrm{m}$ thickness (Merck, Darmstadt, Germany) were used for all determinations. The plates were pre-washed with methanol and activated at $60{ }^{\circ} \mathrm{C}$ for $5 \mathrm{~min}$, prior to chromatography. Five different aliquots $(2,4,8,12$, and $16 \mu l)$ of standard solutions were applied in triplicates on $20 \times$ $10 \mathrm{~cm}$ TLC plates for the preparation of the calibration curve. Six such plates were prepared. A constant application rate of $0.1 \mu \mathrm{s} \mathrm{s}^{-1}$ was employed with a bandwidth of $6 \mathrm{~mm}$. Bandwidth was set at $20 \mathrm{~nm}$. The mobile phase $(10 \mathrm{ml})$ consisted of toluene, ethyl acetate, formic acid, and methanol (3:6: 1.6: 0.4) (v/v). The chamber saturation time for mobile phase was $15 \mathrm{~min}$ (optimum) at relative humidity of $60 \% \pm 5$. The chromatogram run length was $8.0 \mathrm{~cm}$. After development, chromatographic 
plates were dipped into derivatization reagent, i.e., modified Dragendorff reagent and again dried for $10 \mathrm{~min}$ using hair drier on hot mode. After drying, the plates were heated at $70{ }^{\circ} \mathrm{C}$ for $15 \mathrm{~min}$ in a pre-heated oven. The formation of orange-colored spots corresponding to various phytocompounds of plant (fruit peel of Citrus aurantifolia and Punica granatum) extracts was observed. The plates were scanned within $10 \mathrm{~min}$ using a densitometric scanner III in the remission mode at 254 $\mathrm{nm}$. The spots and or peaks were detected and their Rf values, and peak areas were calculated.

\subsection{Identification of the optimum alloxan-monohydrate dose to induce diabetes}

Intraperitoneal optimum dose of alloxan to induce diabetes was done by using a logarithmic scale with 5 dose levels (50,100, 150, 200, and $250 \mathrm{mg} / \mathrm{kg}$ body weight) [12]. The doses were intraperitoneally administered in $0.1 \mathrm{ml}$ physiological saline once for each level to five albinos Wister rats. The animals were frequently monitored for changes in blood sugar within 24 to $48 \mathrm{~h}$. Any fatality, body weakness, or abnormality observed at any dose level was recorded. After $48 \mathrm{~h}$, the diabetic animals were examined for suitability in the bioassays by measuring blood glucose levels after every $2 \mathrm{~h}$ consistently for $24 \mathrm{~h}$. The observations were compared, and the optimum dose was selected for further studies.

\subsubsection{Induction of hyperglycemia}

Hyperglycemia was induced in albino Wister rats from both sexes aged 6 months (180-220 g body weight) experimentally by intraperitoneal administration of a single dose of $150 \mathrm{mg} / \mathrm{kg}$ body weight (identified as optimum dose) of a freshly prepared $10 \%$ alloxan monohydrate (2, 4,5,6 tetraoxypyrimidine; 5-6-dioxyuracil) obtained from Sigma (Steinhein, Switzerland). Blood glucose level was measured using a glucometer after $48 \mathrm{~h}$. Rats with fasting blood glucose $\geq 200 \mathrm{mg} / \mathrm{dl}$ were considered as diabetic. Before initiation of this experiment, the animals were fasted for 8-12 h but providing water until the end of this experiment and maintained at room temperature in plastic cages [13].

\subsubsection{Acute toxicity study}

Acute toxicity was calculated and determined according to the method of Lorke [14]. Wistar albino rats weighing between 150 and $220 \mathrm{~g}$ were used for the study. In the first phase, rats were distributed to four groups of four animals each with four groups as control ( $1 \mathrm{ml}$ saline). Methanolic extracts of Citrus aurantifolia and Punica granatum $(250,500,1000,1500,2000 \mathrm{mg} / \mathrm{kg})$ were administered. In the second phase, three higher doses of 1000,1500 , and $2000 \mathrm{mg} / \mathrm{kg}$ of the extract were administered to each rat from each group. The animals were monitored for $24 \mathrm{~h}$ for behavior and mortality. Further, they were all placed for more observation for $72 \mathrm{~h}$ (3 days) for the signs of physical changes, lethality, toxic symptoms, behavioral changes, or deaths.

\subsubsection{Experimental design}

Among the different solvents used, only methanolic extracts were taken and used to determine the hypoglycemic activity of Punica granatum and Citrus aurantifolia. After observing the acute toxicity study, $500 \mathrm{mg}$ of methanol extract of Citrus aurantifolia and Punica granatum were selected as dosage for this study. Doses were prepared in distilled water by dissolving 500 mg of methanol extract of Punica granatum and Citrus aurantifolia with $1 \%$ Tween- 80 as a surfactant. The experimental animals with an average weight of $180-220 \mathrm{~g}$ were randomly divided into five groups of five animals each. The extracts were administered orally for 28 days.

Group I consisted of normal rats orally administered with $1.0 \mathrm{ml}$ physiological saline and fed with normal pellet diet as positive control.

Group II consisted of alloxan-induced diabetic rats orally administered with $1.0 \mathrm{ml}$ physiological saline, as diabetic control (negative control).

Group III consisted of alloxan-induced diabetic rats orally administered with $1.8-2.2 \mathrm{mg}$ of glibenclamide, standard commercial drug ( $10 \mathrm{mg} / \mathrm{kg}$ body weight) in $1.0 \mathrm{ml}$ physiological saline.

Group IV consisted of alloxan-induced diabetic rats orally administered with peel extract of Citrus aurantifolia (500 mg/kg body weight) in $1.0 \mathrm{ml}$ physiological saline.

Group V consisted of alloxan-induced diabetic rats orally administered with peel extract of Punica granatum (500 mg/kg body weight) in $1.0 \mathrm{ml}$ physiological saline respectively.

\subsubsection{Duration of treatment}

The extracts/drug treatment was given orally for 28 days. Fasting blood glucose levels were estimated on $0,7,14$, 21 , and 28 days. Similarly, the blood samples were withdrawn from all animals at 7 days interval up to 28 days by retro-orbital plexus. Serum glucose [15], serum protein [16], serum cholesterol [17], serum triglycerides [18], serum creatinine [19], and serum urea [20] were estimated using standard procedures. The initial body weight and final body weight were also measured. Finally, euthanasia was performed by cervical dislocation under deep anesthesia with $5 \%$ isoflurane.

\subsection{Statistical analysis}

The data were collected from five replicates of each experimental study. Values were expressed as mean of total number of replicates \pm SE and compared with diabetic control. 


\section{Results and discussions}

\subsection{Acute toxicity study}

During the acute toxicity study, the extracts did not produce any drug-induced harmful physical signs and no mortality was detected. There was no lethality and no toxic reaction was observed at any of the doses selected till the end of the treatment. This designates the two extracts as safety product.

\subsection{Phytochemical screening}

Differential occurrence of phytocompounds was observed when different solvent extracts of Punica granatum and Citrus aurantifolia were subjected to phytochemical screening. Among various solvents used, methanolic extract was found to show positive results for the majority of compounds when compared to aqueous, ethyl acetate, petroleum ether, and chloroform solvent. Methanolic peel extracts of Punica granatum showed positive response for alkaloids, carbohydrates, saponins, phenols, tannins, flavanoids, gums, and mucilages (Table 1). Similarly, methanolic extracts of Citrus aurantifolia peel exhibited the presence of phenolic compounds, tannins, flavonoids and glycosides, alkaloids and carbohydrates (Table 1).

\subsection{HPTLC analysis}

HPTLC chromatograms of methanolic solvent extracts were scanned under UV $254 \mathrm{~nm}$. The densitometric scanning at $254 \mathrm{~nm}$ revealed that the methanol extract exhibited 12 peaks in Citrus aurantifolia in $4.0 \mu \mathrm{l}$ concentration in the chromatogram with start $R f$ value at 0.46 and end $R f$ value at 0.55 . The chromatogram starts at the height of 6.7 and ends at 0.4 . The highest peak (8th peak) in the chromatogram was appeared at $R f$ value 0.50 as for the respective marker gallic acid and it showed peak area of 7873.1. Extracts of Punica granatum fruit peel exhibited 13 peaks with different $R f$ values in the chromatogram. The peaks appeared to show start $R f$ at 0.45 and end $R f$ at 0.54 in $4.0 \mu$ l concentration. The chromatogram showed start height at 0.5 and end height at 3.3. The 10th peak in the chromatogram of Punica granatum peels appeared at the same $R f$ value $(0.50)$ as that of the respective marker (standard gallic acid) with peak area 9919.2 (Fig. 1).

\subsection{Antidiabetic potential of fruit peel of Punica granatum} on alloxan-induced diabetic rats

\subsection{1 a) Biochemical parameters}

As expected, the blood glucose level of untreated diabetic rats (negative control) continued to increase significantly from day 1 to day 28. Methanolic peel extracts of Punica granatum exhibited 39\% reduction in fasting blood glucose level at the end of day 28 whereas standard drug reduced the blood sugar level by $44 \%$. In the case of blood glucose level, the diabetic animals treated with standard drug glibenclamide recorded a reduction of $59 \%$ in blood glucose level when compared to individual plant extracts of Punica granatum (47\%). Treatment of diabetic rats with methanolic peel extracts of $P$. granatum and glibenclamide for 28 days exhibited the same level of reduction in serum cholesterol level (58\%). But in the case of serum triglycerides level, diabetic rats, when administered with standard drug glibenclamide, brought down the level triglycerides by $56 \%$. But, P.granatum reduced the triglyceride level by $64 \%$ which was found to be higher than standard drug. Serum creatinine level was found to be reduced by $59 \%$ in those rats

Table 1 Phytochemical screening of extracts of fruit peel of Citrus aurantifolia and Punica granatum

\begin{tabular}{|c|c|c|c|c|c|c|c|c|c|c|}
\hline \multirow[b]{2}{*}{ Extracts } & \multicolumn{5}{|c|}{ Citrus aurantifolia } & \multicolumn{5}{|c|}{ Punica granatum } \\
\hline & $\begin{array}{l}\text { Petroleum } \\
\text { ether }\end{array}$ & Chloroform & $\begin{array}{l}\text { Ethyl } \\
\text { acetate }\end{array}$ & Methanol & Water & $\begin{array}{l}\text { Petroleum } \\
\text { ether }\end{array}$ & Chloroform & $\begin{array}{l}\text { Ethyl } \\
\text { acetate }\end{array}$ & Methanol & Water \\
\hline Alkaloid & - & - & - & + & + & - & - & - & + & - \\
\hline Carbohydrates & - & - & - & + & + & - & - & - & + & + \\
\hline Saponin & - & - & - & - & - & - & - & - & + & - \\
\hline Triterpenoids & - & - & - & - & - & + & + & - & - & - \\
\hline $\begin{array}{l}\text { Phenolic compounds and } \\
\text { tannins }\end{array}$ & - & - & ++ & ++ & - & - & - & - & ++ & - \\
\hline Proteins and amino acids & - & - & - & - & - & - & - & - & - & + \\
\hline Steroids and sterols & + & + & + & + & - & + & + & - & - & - \\
\hline Fixed oil and fat & - & - & - & - & - & - & - & - & - & - \\
\hline Flavones and flavonoids & - & - & ++ & ++ & - & - & - & - & ++ & + \\
\hline Glycosides & - & - & + & + & - & + & + & + & + & + \\
\hline Gums and mucilages & - & - & - & - & - & - & - & - & + & - \\
\hline
\end{tabular}

+++ Maximum

++ Moderate

+Minimum, not detected 
a) HPTLC chromatogram of methanolic extract of C.aurantifolia

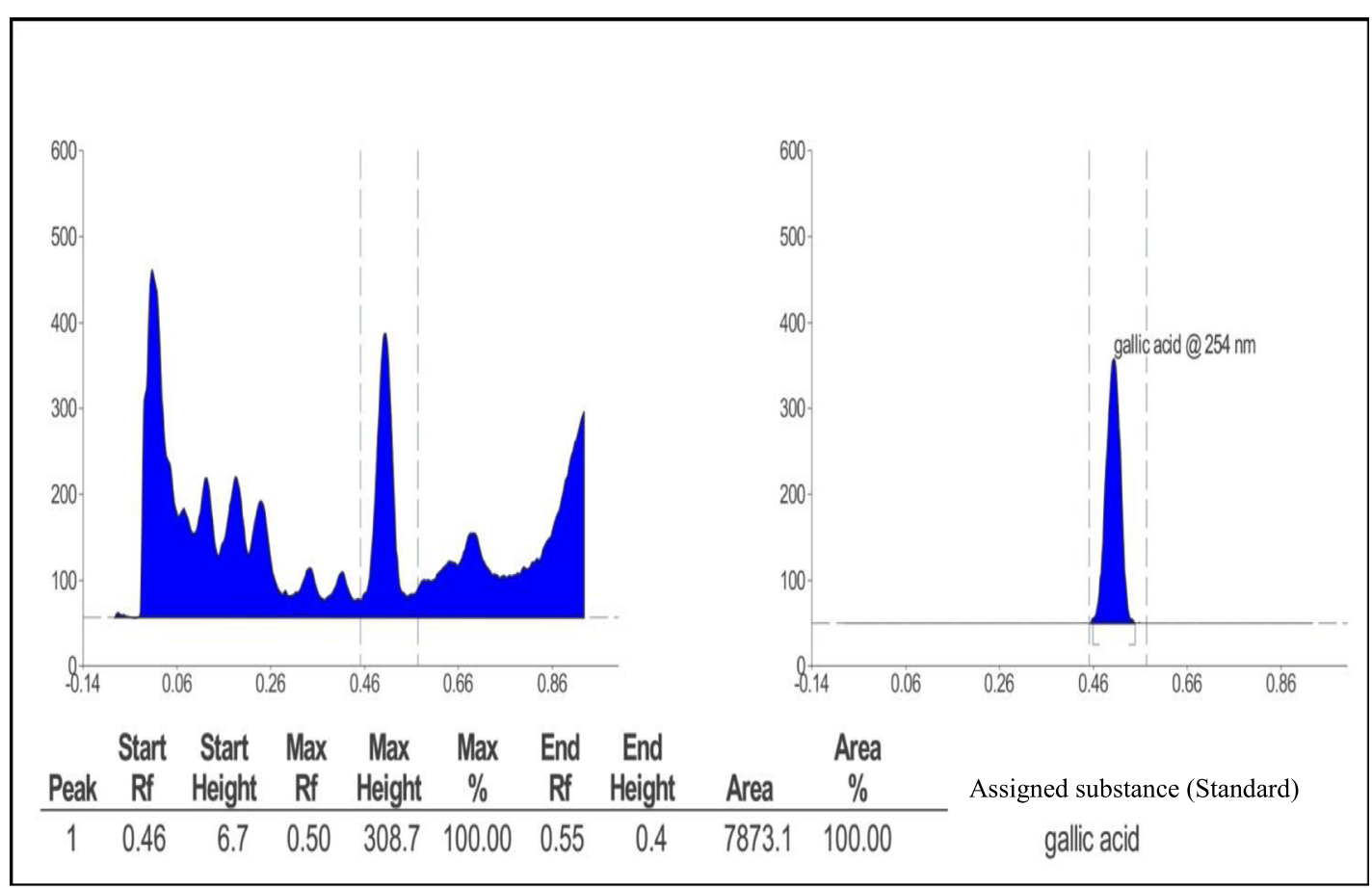

b) HPTLC chromatogram of methanolic extract of P.granatum

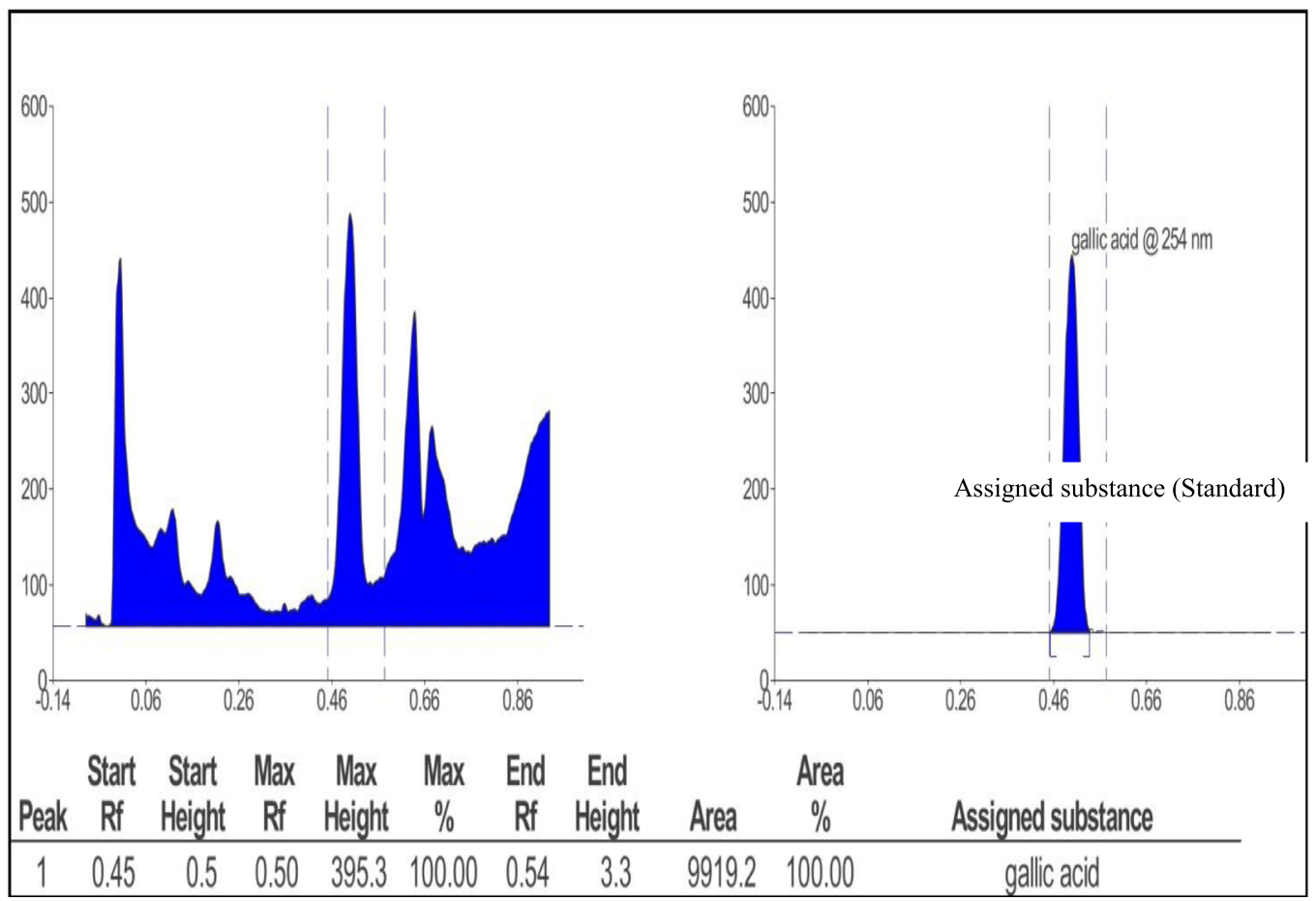

Fig. 1 a HPTLC chromatogram of methanolic extract of C.aurantifolia. b HPTLC chromatogram of methanolic extract of P.granatum 
which were fed with P.granatum peel extract. But, 69\% of reduction in serum creatinine was observed when diabetic rats were fed with standard drug glibenclamide. It was clear that the plant extract exhibited 10\% less reduction efficiency as compared to glibenclamide. At the end of day 28, diabetic rats that received peel extract of P.granatum brought down the level of serum urea by $32 \%$. But, in glibenclamide treated animals, serum urea level was found to be reduced by $41 \%$ which is found to be maximum when compared to individual plant extract. Protein content was found to be enhanced in the diabetic rats, which were supplemented with Punica granatum fruit peel and glibenclamide. In the untreated group, there was a gradual reduction in serum protein level from day1 to day 28 over control. Intraperitoneal administration of Punica granatum peel extracts to alloxan-induced diabetic rats enhanced the protein level in serum by about $38 \%$ over negative control at day 28 . Administration of standard drug glibenclamide also increased the protein level to about 53\% which was comparatively higher when compared to P.granatum treatment (Table 2).

\subsection{2 b) Body weight}

A gradual increase in the body weight of both the normal and control rats and treated diabetic rats was noticed throughout the study. Continuous oral treatment of diabetic rats increased the body weight by $12 \%$. Further, body weight of the diabetic rats was found to be increased by $14 \%$ when rats were fed with glibenclamide drug (Table 2).

\subsection{Antidiabetic potential of fruit peel of Citrus aurantifolia on alloxan-induced diabetic rats 3.5.1 a) Biochemical parameters}

Alloxan induced diabetic rats when treated with glibenclamide and methanolic extracts of Citrus aurantifolia fruit peel showed a gradual decrease in fasting blood glucose level. As expected, the blood glucose level of untreated diabetic rats (diabetic control) continued to increase significantly on the following days. Peel extracts of $C$. aurantifolia exhibited $41 \%$ reduction in the fasting blood glucose level whereas glibenclamide reduced the fasting blood glucose level by $42 \%$. In the case of blood glucose level, diabetic animals treated with standard drug glibenclamide recorded a reduction of $59 \%$ whereas Citrus aurantifolia fruit peel reduced the blood glucose level by $54 \%$. As the days were progressing, on 28 th day, cholesterol level was found to be decreased in alloxaninduced diabetic rats by $56 \%$ and $57 \%$ when treated with methanolic peel extracts of $C$. aurantifolia and glibenclamide respectively. Diabetic rats that received C. aurantifolia peel extract reduced the serum triglycerides level by $65 \%$ which was found to be higher than glibenclamide treatment (56\%). Moreover, at the end of 28 days treatment, a decrease in serum creatinine by $56 \%$ and serum urea level by $37 \%$ was observed in those diabetic rats which were supplemented with $C$. aurantifolia peel extract. But, glibenclamide treated animals exhibited 69\% of reduction in serum creatinine and $41 \%$ of reduction in serum urea which was found to be more when compared to individual plant extracts. However, the level of protein was influenced considerably by the standard drug and the plant extract. An increase in protein content by $43 \%$ was observed in those rats which were administered with $C$. aurantifolia peel extracts whereas standard drug glibenclamide also increased the protein level to about $53 \%$ which was comparatively higher than C. aurantifolia extracts (Table 3 ).

\subsection{2 b) Body weight}

In case of body weight, a gradual increase in body weight was noticed as the days of treatment was progressed. At the end of 28th day, $12 \%$ and $14 \%$ increase in body weight was recorded in diabetic rats which were fed with C. aurantifolia peel extracts and glibenclamide drug treatment (Table 3).

In general, P.granatum and C. aurantifolia peel extracts exhibited antidiabetic potential which was found to be equal to the performance of standard drug glibenclamide. Both P.granatum and C. aurantifolia extracts exhibited a positive change in all biochemical constituents when compared to diabetic control. The antidiabetic potential of peel extracts of P.granatum and $C$. aurantifolia may be attributed to the qualitative and quantitative occurrence of phytochemical compounds that could have regulated the carbohydrate metabolism and increasing the secretion of $\beta$ cells in islets of the pancreas and thus exhibiting hypoglycemic potential.

\section{Discussion}

Several authors have reported that the red color of peel may be attributed to anthocyanidins, flavanols, flavones and flavanones, punicalin and punicalagin and these compounds exhibit antidiabetic potential [21, 22]. The inedible Punica granatum peel contains as much as three times the total amount of polyphenols, including condensed tannins and catechins, gallocatechins, and prodelphinidins [23]. The antidiabetic activity of medicinal plants may be due to the presence of phenolic compounds, alkaloids, terpenoids, and flavonoids [2426]. Preliminary screening of $C$. aurantifolia fruit and other parts showed the presence of alkaloids, carotenoids, coumarins, essential oils, flavanoids, tannins, saponins, steroids, cardiac glycosides, carbohydrates, phenols, and reducing sugars [27-30] Besides citrus pulps, citrus peels are also a promising source of bioactive compounds, which are rich in carotenoids, phenolic acids, 


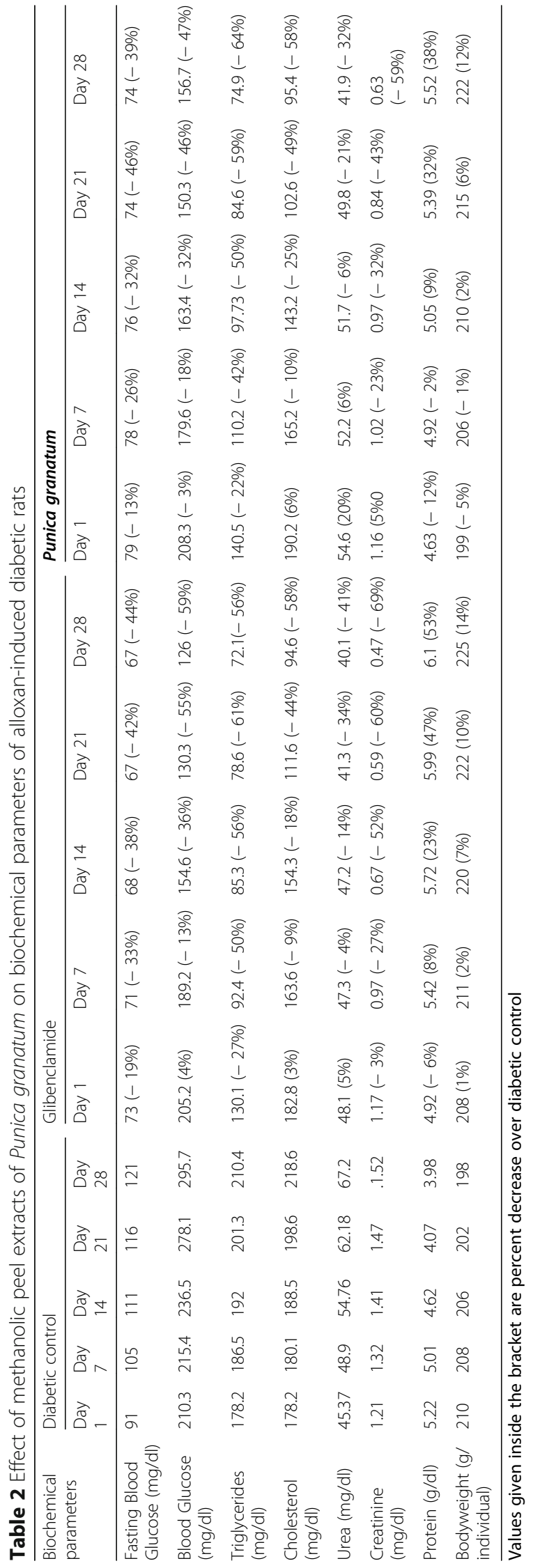




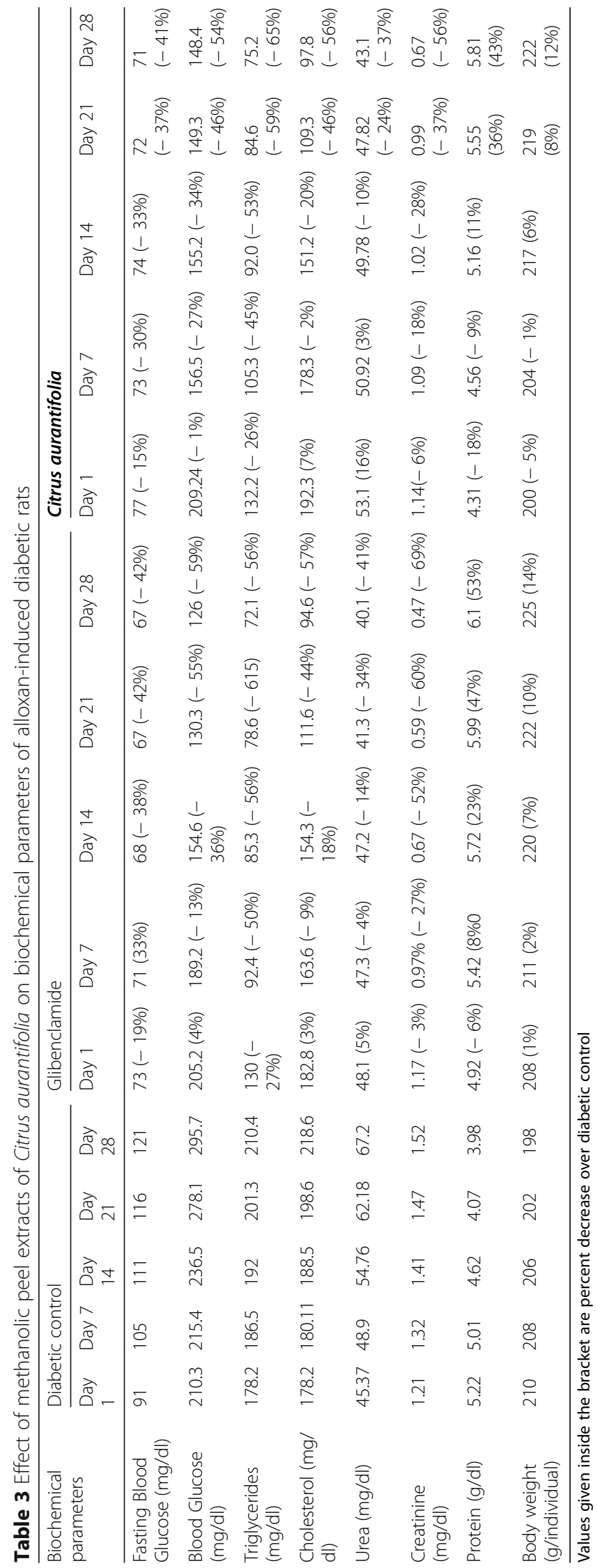


flavonoids, terpenoids, and vitamin C [31]. In citrus fruits, peels are reported to possess the highest amounts of polymethoxylated flavones compared to other edible parts of the fruit [32]. In our study, methanolic extract of Punica granatum and Citrus aurantifolia peel possessed phytochemical compounds such as phenols, flavanoids, alkaloids, etc., which might have regulated the key metabolic pathways such as carbohydrate metabolism, triggering the insulin secretion and enhancing the glucose tolerance.

Gallic acid or 3, 4, 5-trihydroxybenzoic acid is a phenolic acid that exerts antioxidant, anticancer, antiviral, and many other biological effects [33, 34]. In addition to punicalagin, major phenolic compounds such as gallic acid and ellagic are also found to be present in P. granatum fruit peel [35] which are responsible for reduced oxidative stress, lipid peroxidation, $\alpha$-glucosidase inhibition and enhanced uptake of glucose [36].. Similarly, the result of the current study was coincided with another author who examined the gallic acid was extracted by the fruit rind of $P$. granatum which was identified in TLC chromatographic method [37] which can regenerate beta cells and enhance glucose uptake via GLUT4 [38]. Oral administration of gallic acid to both streptozotocin and alloxan-induced diabetic rats significantly reduced blood glucose level [39], lowered plasma levels of the creatinine and elevated the levels of the protein [40].. Ethyl acetate fraction of Punica granatum peel consisted of the highest amount of gallic acid and ellagic acid and concluded that these two polyphenolic compounds were responsible for antidiabetic activity [41]. In our current study, gallic acid was also found in both Citrus aurantifolia and Punica granatum peels which might have involved in inhibition of $\alpha$-amylase and $\alpha$-glucosidase activity, modulation of glucose release and output from liver, improving $\beta$-cell regeneration, insulin secretion, and lipid profile.

In a study, aqueous fruit extract of Punica granatum had a positive effect on the short-term and long-term by lowering the blood glucose levels in alloxan diabetic rats and also concluded that the positive effect may be associated with enhanced $\beta$-cell function and decreasing fasting blood glucose level [42]. Oral treatment with 500 $\mathrm{mg} / \mathrm{kg}$ of $P$. granatum peel extracts to streptozotocin treated guinea pigs revealed significant protective properties with respect to body weight gain and other biochemical parameters such as fasting serum glucose, serum protein, serum cholesterol, serum triglyceride, serum blood urea nitrogen, and serum creatinine level [43]. Peel extract of $P$. granatum significantly reduced the blood glucose, total cholesterol, triglyceride levels, increased the high-density lipoprotein cholesterol level and also concluded that possible mechanism for this anti-diabetic action may be due to enhanced glycemic control and insulin secretion from pancreatic $\beta$ cells in diabetic rats which further exemplifies that Punica granatum peels have hepatoprotective and hypolipidemic actions [44, 45]. Also, ethanolic extracts of seed and rind of Punica granatum when administered on alloxaninduced diabetic albino rats significantly lowered the rise in blood glucose in which rind extract exhibited significantly better activity than seed extract [46]. Hydroalcoholic extract of the peel of Punica granatum powder at a dose of $200 \mathrm{mg} / \mathrm{kg}$ for 28 days showed significant antidiabetic activity [47].

Intraperitoneal administration of C. aurantifolia oil Dlimonene (extracted from peel) to hyperglycemic rats caused a significant reduction in fasting blood, hepatic glucose, serum cholesterol, triacylglycerol which may be due to modulation of glycogen metabolism by $\mathrm{D}$ limenone [48]. On the contrary, the administration of $C$. aurantifolia juice (50\%), lead to reduce blood glucose levels initially and continuous supplementation of lime juice $(50 \%)$ for 21 days produced no significant difference in plasma glucose level of diabetic rats [49]. But, presence of anthocyanin in the Aporo decoction, a decoction made by boiling whole lime fruits (Citrus aurantifolia), including both the rind and the lime juice reduced the blood glucose and triglyceride level than the standard hypoglycaemic drug glibenclamide [50].

\section{Conclusion}

Fruit peels are commonly discarded in both domestic and industrial processing. It serves as an important source for the isolation and extraction of bioactive compounds and also opens up a new avenue for food and pharmaceutical industry. The beneficial effects of peel extract may be attributed to its wide range of active bioactive compounds present in Citrus aurantifolia and Punica granatum peels which might have played a vital role in controlling the diabetic condition by increasing the insulin secretion, reducing hepatic glucose output, regulating certain enzymes that are involved in carbohydrate metabolism. Therefore, it is important to characterize the secondary plant metabolites (phytochemicals) and also to unveil their mode of action in controlling this multifactorial endocrine disorder.

\section{Abbreviations \\ HPTLC: High Performance Thin Layer Chromatography; GLUT4: Glucose transporter type 4; TLC: Thin layer chromatography; RF: Retardation factor; UV: Ultraviolet; HDL: High density lipoprotein; LDL: Low density lipoprotein; MKU: Madurai Kamaraj University; IAEC: Institutional Animal Ethical Committee; KMCP: K.M.College of Pharmacy; TNAU: Tamil Nadu Agricultural University}

\section{Acknowledgements}

We would like to thank Dr. P. Ramkumar, Vice Principal, Ultra College of Pharmacy, Madurai for his valuable suggestions for the completion of this research work. 


\section{Authors' contributions}

SRS designed and outlined the study. BP supervised the collection of plant materials and carried out the determinations. ES and UV performed HPTLC analysis. VN drafted and revised the manuscript. All authors have approved the manuscript for submission.

\section{Funding}

No funding was obtained for this study.

\section{Availability of data and materials}

Data are available from the authors upon reasonable request and permission from the corresponding author's institution.

\section{Ethics approval and consent to participate}

We would like to state that a written consent and approval has been obtained from the institution to use the animals for this study. Animal studies work was carried out in Ultra College of Pharmacy, Madurai, by following their guidelines regarding protocols and procedures after getting prior approval from the Institutional Animal Ethical Committee, of Ultra College of Pharmacy, Madurai (approval number: MKU/IAEC/KMCP/88/P9718 Ph.D./2013).

\section{Consent for publication}

Not applicable

\section{Competing interests}

The authors declare that they have no competing interests.

\section{Author details}

'Department of Biochemistry, Sri Sarada Niketen College for Women, Amaravathipudur, affiliated to Alagappa University, Karaikudi, Tamil Nadu, India. ${ }^{2}$ Department of Botany, Arumugam Pillai Seethai Ammal College, Thiruppathur, affiliated to Alagappa University, Karaikudi, Tamil Nadu, India. ${ }^{3} \mathrm{PG}$ and Research Department of Botany, Raja Doraisingam Government Arts College, Sivagangai, affiliated to Alagappa University, Karaikudi, Tamil Nadu, India. ${ }^{4} \mathrm{PG}$ and Research Department of Botany, Pasumpon Thiru Muthuramalingam Memorial College, Kamuthi, affiliated to Alagappa University, Karaikudi, Tamil Nadu, India. ${ }^{5}$ Centre for Research in Botany, Saraswathi Narayanan College Madurai, affiliated to Madurai Kamaraj University, Chennai, Tamil Nadu, India.

Received: 17 September 2019 Accepted: 3 April 2020 Published online: 16 June 2020

\section{References}

1. Aubert RE, Hilary KWH (2000) Global Burden of Diabetes,1995-2025. Prevalence, numerical estimates, and projections. Diabetes Care 21:1414-1431

2. Wen J, Zhang JQ, Huang W, Wang Y (2012) SDF-1a and CXCR4 as therapeutic targets in cardiovascular disease. Am J Cardiovasc Dis 2:200-208

3. Stein SA, Lamos EM, Davis SN (2013) A review of the efficacy and safety of oral antidiabetic drugs. Expert Opin. Drug Saf. 12:153-175. https://doi.org/ 10.1517/14740338.2013.752813

4. Arumugam G, Manjula P, Paari N (2013) A review: anti diabetic medicinal plants used for diabetes mellitus. J Acute Dis 2:196-200. https://doi.org/10 1016/s2221-6189(13)60126-2

5. Rudra SG, Nishad J, Jakhar N, Kaur C (2015) Food industry waste: mine of nutraceuticals. Int. J Sci Enviroment Technol 4:205-229

6. Park J, Lee M, Park E (2014) Antioxidant activity of orange flesh and peel extracted with various solvents. Prev Nutr Food Sci 19(4):291-298

7. Gamble JS (1935) The flora of the presidency of Madras. Adlard and Son's Ltd, London

8. Mathew KM (1991) An excursion flora of central Tamil Nadu: Oxford and IBH Publishing Co. Pvt Ltd, New Delhi

9. Trease GE, Evans WC(1996) Pharmacognosy, W.B.Saunders, Philadelphia, 4th.

10. Sofowara A (1993) Medicinal plants and traditional medicine in Africa. Spectrum Books Ltd, Ibadan, pp 191-289

11. Sethi PD (1996) High performance thin layer chromatography (HPTLC). CBS Publishers, New Delhi, pp 3-62

12. Thomson EB (1985) Drug bioscreening: fundamentals of drug evaluation techniques in pharmacology. Graceway Publishers Co., New York, pp $150-163$
13. Rees DA, Alcolado JC (2005) Animal models of diabetes mellitus. Diabet Med 22:359-370. https://doi.org/10.1111/j.1464-5491.2005.01499.x

14. Lorke D (1983) A new approach to practical acute toxicity testing. Arch Toxicol 54:275-287

15. Trinder P (1969) Determination of blood glucose using an oxidaseperoxidase system with a non carcinogenic chromogen. J Clin Pathol 22: 158-161. https://doi.org/10.1136/jcp.22.2.158

16. Rajagopal G, Ramakrishnan S (1983) Practical biochemistry for medical students. Orient Longman, Hyderabad

17. Zlatkis A, Zak B, Boyle AJ (1953) A new method for the direct determination of serum cholesterol. J Lab Clin Med 41:486-492. https://doi.org/10.5555/uri: pii:002221435390125

18. Werner M, Gabrielson DG, Eastman J (1981) Ultramicro determination of serum triglycerides by bioluminescent assay. Clin. Chem. 27:268-271

19. Owen JA, lggo B, Scandrett FJ, Stewart CP (1954) The determination of creatinine in plasma or serum, and in urine; a critical examination. Biochem J 58:426-437. https://doi.org/10.1042/bj0580426

20. Varley H (1991) Principle of determination of blood urea by diacetyl monoxime method. Pract Clin Biochem 5:459

21. Middha SK, Usha T, Pande V $(2013,2013)$ A review on antihyperglycemic and antihepatoprotective activity of eco-friendly Punica granatum peel waste. Evid Based Complement Altern Med. https://doi.org/10.1155/2013/656172

22. Bharti SK, Krishnan SK, Ashwini K, Awanish (2018) Antidiabetic phytoconstituents and their mode of action on metabolic pathways. Ther Adv Endocrinol Metab 9:81-100. https://doi.org/10.1177/2042018818755019

23. Ozcan MM, Dursun N, Saǧlam C (2011) Heavy metals bounding ability of pomegranate (Punica granatum) peel in model system. Int J Food Prop 14: 550-556. https://doi.org/10.1080/10942910903262137

24. Subramanian SP, Prasath GS (2014) Antidiabetic and antidyslipidemic nature of trigonelline, a major alkaloid of fenugreek seeds studied in high-fat-fed and low-dose streptozotocin-induced experimental diabetic rats. Biomed Prev Nutr 4:475-480. https://doi.org/10.1016/j.bionut.2014.07.001

25. Cherng YG, Tsai CC, Chung HH, Lai YW, Kuo SC, Cheng JT (2013) Antihyperglycemic action of sinapic acid in diabetic rats. J Agric Food Chem 61:12053-12059. https://doi.org/10.1021/jf403092b

26. Bahadoran Z, Mirmiran P, Azizi F (2013) Dietary polyphenols as potential nutraceuticals in management of diabetes: a review. J Diabetes Metab Disord 12:1. https://doi.org/10.1186/2251-6581-12-43

27. Sunday Enejoh O, Oladejo Ogunyemi I, Smart Bala M, Sotonye Oruene I, Musa Suleiman M, Folorunsho Ambali S (2015) Ethnomedical Importance of Citrus aurantifolia (Christm) swingle. Pharma Innov J 4:1-6

28. Singh P (2019) In vitro study of antibacterial activity by citrus aurantifolia fruit peel, citrus limetta fruit peel and Citrus aurantifolia leaves against oral pathogens. Microb Biochem Technol:31-35. https://doi.org/10.4172/19485948.1000411

29. Narang N, Jiraungkoorskul W (2016) Anticancer activity of key lime, Citrus aurantifolia. Pharmacogn Rev. https://doi.org/10.4103/0973-7847.194043

30. Rauf A, Uddin G, Ali J (2014) Phytochemical analysis and radical scavenging profile of juices of Citrus sinensis, Citrus anrantifolia, and Citrus limonum. Org Med Chem Lett 4:5. https://doi.org/10.1186/2191-2858-4-5

31. Ernawita M, Wahyuono R, Hesse J, Hipler UC, Elsner P, Böhm V (2017) In vitro lipophilic antioxidant capacity, antidiabetic and antibacterial activity of citrus fruits extracts from aceh, indonesia. Antioxidants 6:11. https://doi.org/ 10.3390/antiox6010011

32. Wang $L$, Wang J, Fang $L$, Zheng Z, Zhi D, Wang $S$, Li S, Ho CT, Zhao H (2014) Anticancer activities of citrus peel polymethoxyflavones related to angiogenesis and others. Biomed Res Int 2014:1-10. https://doi.org/10.1155/ 2014/453972

33. Adefegha SA, Oboh G, Ejakpovi II, Oyeleye SI (2015) Antioxidant and antidiabetic effects of gallic and protocatechuic acids: a structure-function perspective. Comp Clin Path 24:1579-1585. https://doi.org/10.1007/s00580015-2119-7

34. Chen GH, Lin YL, Hsu WL, Hsieh SK, Tzen JTC (2015) Significant elevation of antiviral activity of strictinin from Pu'er tea after thermal degradation to ellagic acid and gallic acid. J Food Drug Anal 23:116-123. https://doi.org/10. 1016/j.jfda.2014.07.007

35. Saxena R, Sharma R, Nandy BC (2017) Chromatographic determination of phenolic profile from Punica granatum fruit peels. Int Res J Pharm 8:61-65. https://doi.org/10.7897/2230-8407.080112

36. Arun KB, Jayamurthy P, Anusha CV, Mahesh SK, Nisha P (2017) Studies on activity guided fractionation of pomegranate peel extracts and its effect on 
antidiabetic and cardiovascular protection properties. J Food Process Preserv 41:1-12. https://doi.org/10.1111/jfpp.13108

37. Al-Mosawe EH, Saadi IIA (2012) The extraction and purification of gallic acid from the pomegranate rind. J Sci Al-Mustansiriyah 23:53-60

38. Gandhi GR, Jothi G, Antony PJ, Balakrishna K, Paulraj MG, Ignacimuthu S, Stalin A, Al-Dhabi NA (2014) Gallic acid attenuates high-fat diet fedstreptozotocin-induced insulin resistance via partial agonism of PPARY in experimental type 2 diabetic rats and enhances glucose uptake through translocation and activation of GLUT4 in PI3K/p-Akt signaling pathway. Eur J Pharmacol 745:201-216. https://doi.org/10.1016/j.ejphar.2014.10.044

39. Ramkumar KM, Vijayakumar RS, Vanitha P, Suganya N, Manjula C, Rajaguru P, Sivasubramanian S, Gunasekaran P (2014) Protective effect of gallic acid on alloxan-induced oxidative stress and osmotic fragility in rats. Hum Exp Toxicol 33:638-649. https://doi.org/10.1177/0960327113504792

40. Garud MS, Kulkarni YA (2018) Gallic acid attenuates type I diabetic nephropathy in rats. Chem Biol Interact 282:69-76. https://doi.org/10.1016/j. cbi.2018.01.010

41. Šavikin K, Živković J, Alimpić A, Zdunić G, Janković T, Duletić-Laušević S, Menković N (2018) Activity guided fractionation of pomegranate extract and its antioxidant, antidiabetic and antineurodegenerative properties. Ind Crops Prod 113:142-149. https://doi.org/10.1016/j.indcrop.2018.01.031

42. Montasser Kouhsari S, Gharib E (2018) Study of the antidiabetic activity of Punica granatum $L$. fruits aqueous extract on the Alloxan-diabetic Wistar rats (winter 2019). Iran J Pharm Res:358-368. https:/doi.org/10.22037/ijpr.2019.2324

43. Hasona NASA, Qumani MA, Alghassab TA, Alghassab MA, Alghabban AA (2017) Ameliorative properties of Iranian Trigonella foenum-graecum L. seeds and Punica granatum L. peel extracts in streptozotocin-induced experimental diabetic guinea pigs. Asian Pac J Trop Biomed 7:234-239. https://doi.org/10.1016/j.apjtb.2016.12.004

44. Saad EA, Hassanien MM, El-Hagrasy MA, Radwan KH (2015) Antidiabetic, hypolipidemic and antioxidant activities and protective effects of Punica granatum peels powder against pancreatic and hepatic tissues injuries in streptozotocin induced iddm in rats. Int J Pharm Pharm Sci 7:397-402

45. Radhika S, Smila KH, Muthezhilan R (2011) Antidiabetic and hypolipidemic activity of Punica granatum Linn on alloxan induced rats. World J Med Sci 6: 178-182

46. Das S, Sarma G (2009) Antidiabetic action of ethanolic extracts of Punica granatum Linn. in alloxan-induced diabetic rats. Stamford J Pharm Sci 2:14-21

47. Salwe K, Sachdev D, Bahurupi Y, Kumarappan M (2015) Evaluation of antidiabetic, hypolipedimic and antioxidant activity of hydroalcoholic extract of leaves and fruit peel of Punica granatum in male Wistar albino rats. J Nat Sci Biol Med 6:56. https://doi.org/10.4103/0976-9668.149085

48. Ibrahim FA, Usman LA, Akolade JO, Idowu OA, Abdulazeez AT, Amuzat AO (2019) Antidiabetic potentials of Citrus aurantifolia leaf essential oil. Drug Res (Stuttg). 69:201-206. https://doi.org/10.1055/a-0662-5607

49. Karimi N, Nasab NK (2014) Effect of garlic extract and Citrus aurantifolia (lime) juice and on blood glucose level and activities of aminotransferase enzymes in streptozotocin-induced diabetic rats. World J Pharm Sci 2:821-827

50. Owa SO, Taiwo AA, Okosun JA, Otohinoyi DA, Akujobi YO, Oyewale DG, Ibraheem O, Edewor-Ikupoyi Tl, Adeyemi OS (2016) The biochemical effects of lime concentrate "Aporo" and Mucuna pruriens seeds extract on alloxaninduced diabetic rats. J Taibah Univ Med Sci 11:260-267. https://doi.org/10. 1016/j.jtumed.2016.02.004

\section{Publisher's Note}

Springer Nature remains neutral with regard to jurisdictional claims in published maps and institutional affiliations.

\section{Submit your manuscript to a SpringerOpen ${ }^{\circ}$ journal and benefit from:}

- Convenient online submission

- Rigorous peer review

- Open access: articles freely available online

High visibility within the field

- Retaining the copyright to your article

Submit your next manuscript at $\boldsymbol{\nabla}$ springeropen.com 